\title{
Occupational asthma due to formaldehyde
}

\author{
P SHERWOOD BURGE, MG HARRIES, WK LAM, IM O'BRIEN, PA PATCHETT
}

From the Department of Thoracic Medicine, East Birmingham Hospital, Birmingham, and the Department of Allergy and Clinical Immunology, Cardiothoracic Institute, London

ABSTRACT Bronchial provocation studies on 15 workers occupationally exposed to formaldehyde are described. The results show that formaldehyde exposure can cause asthmatic reactions, and suggest that these are sometimes due to hypersensitivity and sometimes to a direct irritant effect. Three workers had classical occupational asthma caused by formaldehyde fumes, which was likely to be due to hypersensitivity, with late asthmatic reactions following formaldehyde exposure. Six workers developed immediate asthmatic reactions, which were likely to be due to a direct irritant effect as the reactions were shorter in duration than those seen after soluble allergen exposure and were closely related to histamine reactivity. The breathing zone concentrations of formaldehyde required to elicit these irritant reactions (mean $4.8 \mathrm{mg} / \mathrm{m}^{3}$ ) were higher than those encountered in buildings recently insulated with urea formaldehyde foam, but within levels sometimes found in industry.

Formaldehyde has been described as a sporadic cause of occupational asthma since the first report in a matchmaker in 1939.' Case reports describe occupational asthma in a rubber tyre worker, ${ }^{2}$ a laboratory worker, ${ }^{3}$ and two nurses in a renal dialysis unit. ${ }^{4}$ Formaldehyde is extremely widely used in industry with production in the United States exceeding 3600 million $\mathrm{kg}$ ( 8000 million $\mathrm{lb}$ ) a year for use in the chemical, construction, textile, paper, plastic, paint, adhesive, and cosmetic industries. More recently urea formaldehyde has been widely used for cavity wall insulation and for making particle board for mobile homes. Many symptoms have been attributed to living in such homes, including some symptoms suggestive of asthma.$^{6-8} \mathrm{We}$ report our experience with bronchial provocation testing with formaldehyde in 15 workers occupationally exposed to formaldehyde who had respiratory symptoms thought to be work related. Ten of the workers were also exposed to other agents known to cause occupational asthma.

Address for reprint requests: Dr PS Burge, Department of Thoracic Medicine, East Birmingham Hospital, Birmingham B9 5ST.

Accepted 10 December 1984

\section{Subjects and methods}

\section{SUBJECTS}

All those studied were referred for investigation after presenting with symptoms suggestive of occupational asthma. The details of the workers are shown in table 1. Brief histories are given of subjects $1-3$, who had evidence of specific hypersensitivity to formaldehyde, and of subjects 4 and 5 in whom presenting symptoms were likely to be due to irritant reactions to formaldehyde. Subjects 6-14 were all additionally exposed to other materials likely to be the cause of their symptoms.

Subject 1 A 62 year old plastics moulder developed cough, sputum, chest tightness, and breathlessness after a few hours at work, and particularly after returning home from work. He would wake frequently from sleep with breathlessness. His symptoms were worse after night shifts than day shifts and always improved during holidays. He first noticed wheeze 24 years after starting work as a phenolic moulder. His job involved preheating a cake of phenol formaldehyde or melamine formaldehyde before putting it into a manually operated compression moulding machine.

Subject 2 A 29 year old printer developed swollen sore eyes, a running nose, and headache three months after starting to mix Coates printing ink con- 
Table 1 Details of subjects

\begin{tabular}{|c|c|c|c|c|c|c|c|c|c|c|}
\hline $\begin{array}{l}\text { Subject } \\
\text { No }\end{array}$ & Age & Sex & $J o b$ & $\begin{array}{l}\text { Interval from } \\
\text { first formaldehyde } \\
\text { exposure to onset } \\
\text { of asthmatic } \\
\text { symptoms }\end{array}$ & Smoking & $\begin{array}{l}\text { Previous } \\
\text { asthma or } \\
\text { rhinitis }\end{array}$ & Atopy & $\begin{array}{l}\text { Other } \\
\text { exposures }\end{array}$ & $\begin{array}{l}\text { History of } \\
\text { late reaction }\end{array}$ & $\begin{array}{l}\text { Symptoms } \\
\text { to } \\
\text { formaldehyd }\end{array}$ \\
\hline 1 & 62 & $\mathbf{M}$ & Plastic moulder & 24 years & 0 & 0 & 0 & phenol & + & + \\
\hline 2 & 29 & $\mathbf{F}$ & Printer & 0.5 & Ex & 0 & 0 & - & + & + \\
\hline 3 & 59 & $\mathbf{M}$ & $\begin{array}{l}\text { Manufacturer of } \\
\text { phenol } \\
\text { formaldehyde }\end{array}$ & 24 & + & 0 & 0 & phenol & + & + \\
\hline 4 & 62 & $\mathbf{M}$ & Medicine packer & 12 & Ex (20 y) & Rhinitis (14 y) & + & gold paint & 0 & + \\
\hline 5 & 45 & $\mathbf{M}$ & Farmworker & $\begin{array}{l}20 \text { ys small } \\
\text { amount then } \\
\text { single large } \\
\text { exposure }\end{array}$ & Ex & 0 & 0 & hay, grain, etc & 0 & + \\
\hline 6 & 49 & $\mathbf{M}$ & & 13 & Ex & $\mathbf{0}$ & 0 & isocyanates & + & - \\
\hline 7 & 44 & $\mathbf{M}$ & & 2 & + & 0 & + & isocyanates & + & - \\
\hline 8 & 53 & $\mathbf{M}$ & Printers or & 12 & + & 0 & 0 & isocyanates & + & - \\
\hline 9 & 36 & $\mathbf{M}$ & laminators & 6 & Ex & 0 & 0 & isocyanates & + & - \\
\hline 10 & 26 & $\mathbf{M}$ & of flexible & 4 & 0 & Rhinitis & + & isocyanates & - & - \\
\hline 11 & 41 & $\mathbf{M}$ & packagıng & 5 & 0 & Rhinitis & + & isocyanates & + & - \\
\hline 12 & 45 & $\mathbf{M}$ & & 9 & Ex & 0 & + & isocyanates & + & - \\
\hline 13 & 47 & $\mathbf{M}$ & $\begin{array}{l}\text { Laminated } \\
\text { tray maker }\end{array}$ & 4 & 0 & 0 & 0 & makore & + & - \\
\hline 14 & 52 & $\mathbf{M}$ & $\begin{array}{l}\text { Core shop } \\
\text { worker }\end{array}$ & 18 & 0 & 0 & + & $\begin{array}{l}\text { isocyanates } \\
\text { furanes }\end{array}$ & + & - \\
\hline 15 & 35 & $\mathbf{M}$ & $\begin{array}{l}\text { Core shop } \\
\text { worker }\end{array}$ & 0.5 & + & 0 & + & $\begin{array}{c}\text { isocyanates } \\
\text { furanes }\end{array}$ & + & - \\
\hline
\end{tabular}

taining urea formaldehyde. The symptoms would start within an hour of coming to work and remit two hours after leaving in the evening. Three months later she developed breathlessness with wheeze, particularly at night. Her wheeze was improved when she was away from work.

Subject 3 A 59 year old process worker manufactured phenol formaldehyde. Twenty four years after starting this job he developed asthma towards the end of a work shift, which was sufficiently severe to need one to two weeks off work to recover, on 11 occasions in six months.

Subject 4 A 62 year old man sprayed the necks of medicine bottles with a gold paint containing melamine formaldehyde. After being sprayed the bottles were put in an open oven at $120^{\circ} \mathrm{C}$ for curing. Twelve years after starting this work he developed wheeze and breathlessness. Symptoms would start within minutes of his coming to work and would improve at weekends and during holidays.

Subject 5 A 45 year old farmworker and shepherd developed sneezing, cough, sputum, breathlessness, and wheeze while making silage that was treated with Sylade, a solution of $25 \%$ formaldehyde in water. His symptoms became persistent during the summer; he attributed this to the sheep dip next to his cottage, which also contained a solution of formaldehyde.

\section{BRONCHIAL PROVOCATION TESTS}

Bronchial provocation tests were carried out in a $6 \mathrm{~m}^{3}$ chamber without air extraction during the test. A saturated solution of formaldehyde was diluted with distilled water to give solutions with $0.1 \%, 1 \%$, $10 \%, 20 \%$, and $25 \%$ of saturated formaldehyde. The Sylade was used as manufactured. The formaldehyde solution was painted on to a paper surface

Table 2 Results of bronchial provocation tests in subject 1

\begin{tabular}{|c|c|c|c|c|c|c|}
\hline \multirow[t]{2}{*}{ Day } & \multirow[t]{2}{*}{ Exposure } & & \multirow{2}{*}{$\begin{array}{l}\text { Duration } \\
\text { (min) }\end{array}$} & \multirow{2}{*}{$\begin{array}{l}\text { Starting } \\
F E V_{1}(l)\end{array}$} & \multicolumn{2}{|c|}{ Maximum \% fall in FEV } \\
\hline & & & & & Immediate & Late \\
\hline $\begin{array}{r}1 \\
2 \\
3 \\
4 \\
8 \\
15 \\
16 \\
17 \\
24\end{array}$ & $\begin{array}{l}\text { Control } \\
\text { Melamine formaldehyde } \\
\text { Melamine formaldehyde } \\
\text { Melamine formaldehyde } \\
\text { Formaldehyde } 25 \% \\
\text { Phenol formaldehyde } \\
\text { Phenol formaldehyde } \\
\text { Phenol formaldehyde } \\
\text { Formaldehyde } 25 \% \\
\text { ( } 9 \text { pm start) }\end{array}$ & $\begin{array}{r}150^{\circ} \mathrm{C} \\
150^{\circ} \mathrm{C} \\
200^{\circ} \mathrm{C} \\
18^{\circ} \mathrm{C} \\
180^{\circ} \mathrm{C} \\
180^{\circ} \mathrm{C} \\
200^{\circ} \mathrm{C} \\
18^{\circ} \mathrm{C}\end{array}$ & $\begin{array}{l}4.5 \\
8 \\
8 \\
12 \\
6 \\
12 \\
30 \\
12\end{array}$ & $\begin{array}{l}1.75 \\
1.95 \\
1.83 \\
1.80 \\
1.88 \\
1.70 \\
1.80 \\
1.80 \\
1.75\end{array}$ & $\begin{array}{r}0 \\
5 \\
7 \\
19 \\
7 \\
12 \\
6 \\
1 \\
20\end{array}$ & $\begin{array}{l}0 \\
23 \\
29 \text { (with rhinitis) } \\
37 \\
22 \\
7 \\
8 \\
19 \\
20\end{array}$ \\
\hline
\end{tabular}


Table 3 Results of bronchial provocation testing with formaldehyde in subjects 2-15

\begin{tabular}{|c|c|c|c|c|c|c|}
\hline \multirow{2}{*}{$\begin{array}{l}\text { Subject } \\
\text { No }\end{array}$} & \multirow{2}{*}{$\begin{array}{l}\text { Histamine } \\
P C_{20}(\mathrm{mg} / \mathrm{ml})\end{array}$} & \multicolumn{2}{|l|}{ Exposure } & \multirow{2}{*}{$\begin{array}{l}\text { Baseline } \\
F E V_{1}(l)\end{array}$} & \multicolumn{2}{|c|}{ Maximum fall in $F E V_{1}$} \\
\hline & & formaldehyde concentration & $\begin{array}{l}\text { Duration } \\
\text { (min) }\end{array}$ & & Immediate (\%) & Late (\%) \\
\hline 2 & $>32$ & $\begin{array}{l}0.1 \% \\
1 \% \\
\text { Ink }\end{array}$ & $\begin{array}{l}30 \\
30 \\
30\end{array}$ & $\begin{array}{l}2.55 \\
2.66 \\
2.6\end{array}$ & $\begin{array}{l}0 \\
17 \\
15 \text { (with rhinitis) }\end{array}$ & $\begin{array}{l}16 \text { (with rhinitis) } \\
23 \\
18\end{array}$ \\
\hline 3 & $>32$ & $\begin{array}{l}1 \% \\
10 \%(2)\end{array}$ & $\begin{array}{l}30 \\
30\end{array}$ & 2.62 & 12 & $\begin{array}{l}18 \\
31\end{array}$ \\
\hline 4 & 2 & $\begin{array}{l}10 \% \\
120^{\circ} \mathrm{C} \text { neogene paint } \\
10 \% \text { (DSCG pretreatment) }\end{array}$ & $\begin{array}{r}30 \\
2 \\
30\end{array}$ & $\begin{array}{l}1.78 \\
2.0 \\
1.65\end{array}$ & $\begin{array}{l}26 \\
27 \\
26\end{array}$ & $\begin{array}{r}9 \\
9 \\
11\end{array}$ \\
\hline 5 & $>32$ & $\begin{array}{l}1 \% \\
10 \% \\
20 \% \\
\text { Sylade }(25 \%)(3)\end{array}$ & $\begin{array}{r}30 \\
30 \\
10 \\
7\end{array}$ & $\begin{array}{l}3.25 \\
3.28 \\
3.38 \\
3.63\end{array}$ & $\begin{array}{l}11 \\
12 \\
15 \\
26\end{array}$ & $\begin{array}{l}0 \\
0 \\
8 \\
9\end{array}$ \\
\hline 6 & 2 & $\begin{array}{l}10 \% \\
\text { Melamine formaldehyde } 200^{\circ} \mathrm{C}\end{array}$ & $\begin{array}{l}30 \\
15\end{array}$ & $\begin{array}{l}2.08 \\
1.98\end{array}$ & $\begin{array}{l}17 \\
18\end{array}$ & $\begin{array}{l}0 \\
0\end{array}$ \\
\hline 7 & $>32$ & $10 \%$ & 30 & 2.8 & $\begin{array}{l}10 \\
12\end{array}$ & 9 \\
\hline 8 & 4 & $10 \%$ & 30 & 1.95 & 18 & 0 \\
\hline 9 & $>32$ & $10 \%$ & 30 & 3.61 & 7 & 6 \\
\hline 10 & $>32$ & $10 \%$ & 30 & 3.27 & 0 & 0 \\
\hline 11 & $>32$ & Melamine formaldehyde $200^{\circ} \mathrm{C}$ & 15 & 3.11 & 4 & 3 \\
\hline 12 & $>32$ & Melamine formaldehyde $200^{\circ} \mathrm{C}$ & 10 & 2.25 & 0 & 0 \\
\hline 13 & $>32$ & $10 \%$ & 30 & 2.25 & 0 & $\mathbf{0}$ \\
\hline & & Phenol formaldehyde $210^{\circ} \mathrm{C}$ & 14 & 2.07 & 8 & 6 \\
\hline $\begin{array}{l}14 \\
15\end{array}$ & $>32$ & $\begin{array}{l}1 \% \\
1 \%\end{array}$ & $\begin{array}{l}30 \\
30\end{array}$ & $\begin{array}{l}1.94 \\
3.0\end{array}$ & $\begin{array}{l}10 \\
10\end{array}$ & $\begin{array}{l}\mathbf{0} \\
\mathbf{0}\end{array}$ \\
\hline
\end{tabular}

Formaldehyde concentration in air: (1) $0.17 \mathrm{mg} / \mathrm{m}^{3}$; (2) $0.33 \mathrm{mg} / \mathrm{m}^{3}$; (3) $31 \mathrm{mg} / \mathrm{m}^{3}$.

with a new paint brush for the duration of the test. For phenol formaldehyde and melamine formaldehyde exposures $1 \mathrm{~g}$ of the moulding powder was heated on a hot plate. Atmospheric concentrations of formaldehyde were measured 11 times during formaldehyde exposure; the samples were taken in the breathing zone of the exposed worker. Formaldehyde was assayed with nitroblue tetrazolium. Thirty minute exposures to the $1 \%$ formaldehyde produced a mean breathing zone concentration of $2.3 \mathrm{mg} / \mathrm{m}^{3}$ and $10 \%$ formaldehyde $4.8 \mathrm{mg} / \mathrm{m}^{3}$. A 10 minute exposure to $20 \%$ formaldehyde resulted in atmospheric concentrations of $13 \mathrm{mg} / \mathrm{m}^{3}$ and a seven minute exposure to Sylade ( $25 \%$ formaldehyde) $31 \mathrm{mg} / \mathrm{m}^{3}$.

\section{HISTAMINE REACTIVITY}

Non-specific bronchial reactivity to histamine was measured on the day before the formaldehyde bronchial provocation test in patients $2-15$. Doubling concentrations of histamine from 0.25 to $32 \mathrm{mg} / \mathrm{ml}$ were inhaled for 30 seconds, with a Wright's nebuliser and rebreathing bag after the method of de Vries. ${ }^{9}$ The dose of histamine required to drop the FEV 1 by $20 \%$ was denoted $\mathrm{PC}_{20}$. Normal subjects do not react at $32 \mathrm{mg} / \mathrm{ml}$, whereas most people with asthma react at concentrations below this.

\section{Results}

Subjects 1-3 had appreciable late asthmatic reac- tions after formaldehyde exposure, suggesting true sensitisation. Subjects $4,5,6$, and 8 had appreciable immediate reactions with no late reaction. The results for the individual exposures are shown in tables 2 and 3.

\section{THE REACTIONS}

Subject 1 Late reactions followed formaldehyde exposure on six occasions. On two of these there was also an appreciable immediate reaction. Late asthmatic reactions reproducibly followed when $1 \mathrm{~g}$ of melamine formaldehyde was heated to $150^{\circ} \mathrm{C}$ and

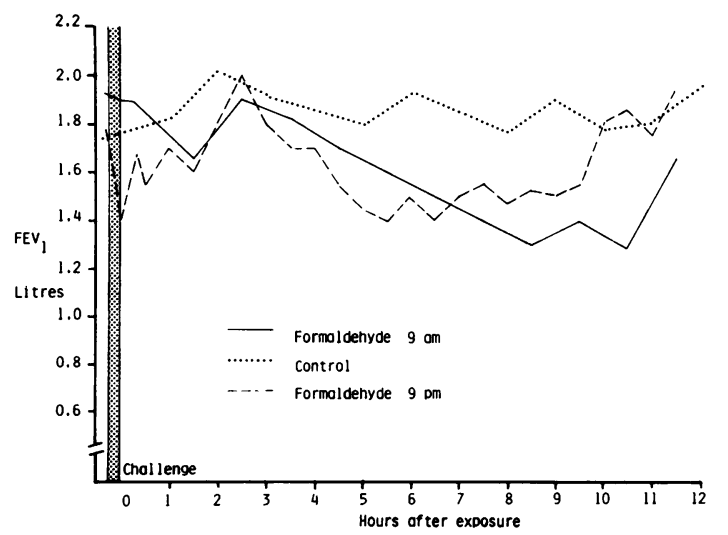

Fig 1 Bronchial provocation testing with $25 \%$ formaldehyde for 12 minutes with exposures starting at 9 am and at 9 pm in subject 1 . 
phenol formaldehyde to $180^{\circ} \mathrm{C}$, and $25 \%$ formaldehyde was breathed at room temperature. An immediate reaction occurred before the late asthmatic reaction on the third day of melamine formaldehyde exposure. Because this man had a history of symptoms that were worse on a night shift the formaldehyde exposure was repeated at $9 \mathrm{pm}$ seven days after his last formaldehyde exposure. He stayed awake for the next 12 hours. The late asthmatic reaction was similar to the reaction that followed the same challenge at $9 \mathrm{am}$, but the $9 \mathrm{pm}$ exposure was followed by a short lasting immediate reaction in addition (fig 1 ). Histamine reactivity was not measured.

Subject 2 Exposure to $0.1 \%$ formaldehyde resulted in a late rhinitic reaction and watering eyes 10 hours after exposure. Exposure to $1 \%$ formaldehyde resulted in a significant dual immediate and late asthmatic reaction. The interpretation of the late reaction was complicated by occasional poorly performed lung function measurements on the control day. Formaldehyde concentrations were $0.17 \mathrm{mg} / \mathrm{m}^{3}$ during the ink exposure.

Subject 3 There was no appreciable immediate or late asthmatic reaction after exposure to $0.1 \%$ phenol or $1 \%$ formaldehyde. Exposure to $10 \%$ formaldehyde was followed by a $31 \%$ fall in FEV nine hours after exposure, indicating a considerable late asthmatic reaction. Formaldehyde concentrations were $0.33 \mathrm{mg} / \mathrm{m}^{3}$ during this exposure. The immediate asthmatic reactions that followed formaldehyde exposure were notable for their short duration. Several subjects developed bronchoconstriction that was made worse by the forced expiratory manoeuvre. This was particularly notice-

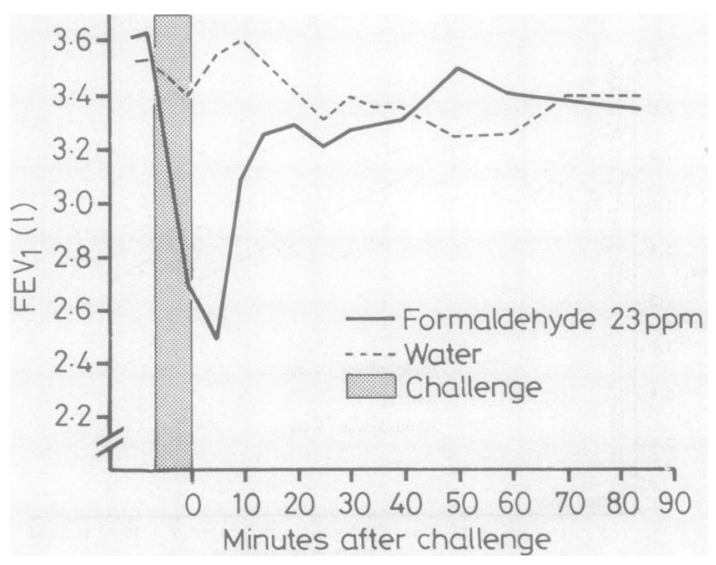

Fig 2 Bronchial provocation testing with Sylade containing $25 \%$ formaldehyde for seven minutes in subject 5. able in subject 1 . On each occasion the best FEV has been taken for the calculation.

\section{RELATIONSHIP BETWEEN HISTAMINE}

REACTIVITY AND FORMALDEHYDE REACTIONS

Three of the four subjects with histamine hyperreactivity had an immediate reaction alone when exposed to $10 \%$ formaldehyde. Three subjects with a normal histamine $\mathrm{PC}_{20}$ value also reacted to formaldehyde; subject 5 reacted to $20 \%$ but not $10 \%$ formaldehyde (fig 2), while subjects 2 and 3 had in addition late asthmatic reactions to formaldehyde. One subject with histamine reactivity (subject 14) and four subjects with normal histamine $\mathrm{PC}_{20}$ values (subjects 2, 3, 5, and 15) failed to respond to $1 \%$ formaldehyde (table 3 ).

\section{Discussion}

The compression moulder, ink maker, and phenol formaldehyde process worker (subjects 1-3) join the few properly documented workers with occupational asthma due to formaldehyde. Subject 1 had his late asthmatic reaction reproduced on seven occasions. Immediate reactions were induced on only two occasions, one after a series of daily exposures to heated melamine formaldehyde and the other when the exposure was in the evening at $9 \mathrm{pm}$. Histamine reactivity was not measured in this worker, but it is known to increase after a late asthmatic reaction. ${ }^{10}$ Histamine reactivity also shows a diurnal variation in asthmatic patients, who have a greater reactivity in the evening. " Possibly therefore his immediate asthmatic reactions occurred only when his non-specific reactivity was greatest. The ink maker and phenol formaldehyde process worker reacted to formaldehyde at concentrations below $0.5 \mathrm{mg} / \mathrm{m}^{3}(0.3 \mathrm{ppm})$.

Previous authors have investigated the effect of relatively low concentrations of formaldehyde in both normal and asthmatic subjects. Thirty seven normal people had no reaction when exposed to $5.2 \mathrm{mg} / \mathrm{m}^{3}$ (3.5 ppm) of formaldehyde. ${ }^{12}$ A similar study in nine asthmatic and nine normal subjects and 10 people with symptoms possibly due to urea formaldehyde foam insulation failed to show any asthmatic response with exposures up to $3.1 \mathrm{mg} / \mathrm{m}^{3}$ (2.1 ppm), although rhinitic reactions occurred in two subjects. ${ }^{13}$ Eleven workers exposed to formaldehyde and isocyanates were exposed to both during bronchial provocation tests. ${ }^{14}$ Only the worker with the greatest non-specific reactivity had a reaction, and this lasted less than five minutes after a 30 minute formaldehyde exposure at $3.7 \mathrm{mg} / \mathrm{m}^{3}$ (2.5 ppm). The present study used exposures well above the threshold limit value, but within those 
encountered in industry. ${ }^{15}$ One per cent formaldehyde (average breathing zone concentration $2.3 \mathrm{mg} / \mathrm{m}^{3}(1.5 \mathrm{ppm})$ ) failed to induce asthma in one worker with severe histamine reactivity in line with the asthmatic patients studied by Frigas. ${ }^{12}$ But all three workers with histamine hyperreactivity exposed to $10 \%$ formaldehyde (average breathing zone concentration $4.8 \mathrm{mg} / \mathrm{m}^{3}(3.2 \mathrm{ppm})$ had an immediate asthmatic reaction. Although no worker with normal histamine reactivity had an immediate reaction to formaldehyde exposure at this level; a higher concentration of $31 \mathrm{mg} / \mathrm{m}^{3} \quad(20.7 \mathrm{ppm})$ resulted in an immediate reaction in one worker with normal histamine reactivity. The close relationship between histamine and formaldehyde reactivity suggests that the two substances are acting by similar (irritant) mechanisms during the immediate reaction. Occupational asthma due to substances which are thought to be working as specific sensitisers, such as isocyanates and colophony, has a less clear relationship with histamine reactivity. ${ }^{16}$ The immediate asthmatic reactions that follow formaldehyde exposure, with their short duration, are different from the reactions seen after soluble allergen exposure. Bronchoconstriction induced by forced expiration occurs in a small proportion of asthmatics, but was a particular feature after formaldehyde exposure. A similar effect was observed after sulphur dioxide exposure in asthmatic patients. ${ }^{17}$ These features suggest that all the immediate reactions we observed were induced by formaldehyde acting as a non-specific irritant. Although sodium cromoglycate can block some irritant reactions, ${ }^{17}$ it is generally less effective at this than in blocking allergen induced immediate reactions. The lack of effect of sodium cromoglycate in subject 4 is therefore in keeping with an irritant mechanism.

The workers described have all had direct exposure to formaldehyde or exposure to melamine formaldehyde or phenol formaldehyde heated to a sufficient temperature to liberate appreciable concentrations of formaldehyde. The late asthmatic reactions to formaldehyde in subjects 1,2 , and 3 were in keeping with their history of occupational asthma. The irritant reaction in the shepherd (subject 5) also accords well with his history. Subject 4 (using a gold paint containing melamine formaldehyde) had a history more suggestive of an allergic occupational asthma. The symptoms of occupational asthma in the other subjects with irritant formaldehyde reactions were all more likely to be due to the isocyanates or wood dusts to which they also reacted, with an allergic type response.

The problem of people exposed to urea formaldehyde used for home insulation is more complicated.
Formaldehyde concentrations in houses within a few days of insulation may reach $1-2 \mathrm{mg} / \mathrm{m}^{3},{ }^{718}$ but are usually lower. One woman who attributed asthma to home insulation with urea formaldehyde has been adequately investigated. ${ }^{19}$ She reacted to the urea formaldehyde taken from the floor of her house but not to newly foamed urea formaldehyde or to formaldehyde alone. Formaldehyde is therefore unlikely to have been the cause of her asthma. Two carpenters working with urea formaldehyde bonded cedar board developed occupational asthma. ${ }^{20}$ Although reactions were greater after exposure to sawdust from the urea formaldehyde bonded board, the differences between this reaction and the reaction that followed following cedar sawdust were small. The role of formaldehyde was not investigated.

The present study suggests that irritant reactions to formaldehyde usually occur at concentrations above those likely to occur with home insulation. These concentrations can be reached in industrial situations, particularly when resins containing formaldehyde are overheated. Given the widespread use of formaldehyde it is surprising how infrequently occupational asthma due to formaldehyde is seen.

We would like to thank Moira Cavanagh for measuring the formaldehyde concentrations, Dr David Henrick for his helpful advice, and Dr A Newman Taylor for permission to report one of the patients.

\section{References}

1 Vaughan WT. The practice of allergy. St Louis: Mosby, 1939:677.

2 Popa V, Teculescu D, Stanescu D, Gavrilescu N. Bronchial asthma and asthmatic bronchitis determined by simple chemicals. Dis Chest 1969;56:395-404.

3 Sakula A. Formalin asthma in hospital laboratory staff. Lancet 1975;ii: 816.

4 Hendrick DJ, Lane DJ. Occupational formalin asthma. $\mathrm{Br} J$ Ind Med 1977;34:11-8.

5 Hendrick DJ, Rando RJ, Lane DJ, Morris MJ. Formaldehyde asthma: challenge exposure levels and fate after five years. $J$ Occup Med 1982;24:893-7.

6 Bandana EJ. Formaldehyde hypersensitivity and irritant reaction at work and in the home. Immunol Allergy Pract 1980;11:11-23.

7 Breysse PA. The health cost of "tight" homes. JAMA 1981;245:267-8.

8 Editorial. The health hazards of formaldehyde. Lancet 1981;i:926-7.

9 De Vries K, Booij-Noord H, Goei JT, et al. Hyperreactivity of the bronchial tree to drugs, chemical and physical agents. In: Orie NGM, Sluiter HJ, eds. Bronchitis Vol II. Assen: Royal van Gorgum, 1964:167.

10 Cockroft DW, Ruffin RE, Dolovich J, Hargreave FE. Allergen induced increase in non-allergic bronchial reactivity. Clin Allergy 1977;7:503-13.

11 De Vries K, Goei JT, Booij-Noord H, Orie NGM. Changes during 24 hours in the lung function and his- 
tamine hyper-reactivity of the bronchial tree in asthmatics and bronchitic patients. Int Arch Allergy 1962;20:93-101.

12 Frigas E, Filley WV, Reed CE. UFFI dust-nonspecific irritant only? Chest 1982;82:511-2.

13 Day JH, Lees REM, Clarke RH. Respiratory effect of formaldehyde and UFFI off-gas following controlled exposure. J Allergy Clin Immunol 1983;71,suppl: 159.

14 Zammit-Tabona M, Sherkin M, Kijek K, Chan H, Chan-Yeung M. Asthma caused by diphenylmethane di-isocyanate in foundry workers. Am Rev Respir Dis 1983; 128:226-30.

15 Yefremov GG. The state of the upper respiratory tract in formaldehyde production employees. Zh Ushn Nos Gorl Bolezn 1970;30:11-5.
16 Burge PS. Non-specific bronchial hyper-reactivity in workers exposed to toluene di-isocyanate, diphenylmethane di-isocyanate and colophony. Eur J Respir Dis 1982;63,suppl 123:91-6.

17 Harries MG, Parkes PEG, Lessof MH, Orr TSC. Role of bronchial irritant receptors in asthma. Lancet 1981;i:5-6.

18 Bernadini P, Carelli G, Valentino R. Formaldehyde in insulated housing. Lancet 1981;ii:375.

19 Frigas E, Filley WV, Reed CE. Asthma induced by dust from urea-formaldehyde foam insulating material. Chest 1981;79:706-7.

20 Cockroft DW, Hoeppner VH, Dolovich J. Occupational asthma caused by cedar urea-formaldehyde particle board. Chest 1982; 82: 49-53. 